\title{
Land of Opportunity? The Assimilation of Scottish Migrants in England, 1603-ca. 1762
}

\section{Keith M. Brown and Allan Kennedy}

\begin{abstract}
Immigration and its consequences is one of the most contentious issues in the contemporary world, and historians are engaged in this debate by offering a longer-term perspective. In recent years, research on the United Kingdom's population has placed greater emphasis on population movement in shaping Britain's story, identifying waves of migrants from elsewhere alongside migration within Britain. One neglected aspect of this narrative, however, is the migration of Scots to England, particularly in the age of the regal and parliamentary union, when the changing political relationship between the two kingdoms had an impact on the scale, geographic spread, and opportunities and obstacles of that migration. While a minority of Scottish migrants were unwelcome, or chose to return home, the overwhelming weight of evidence is for those migrants who remained in England. The focus in this article is on that majority group for whom migration was a positive experience, thus raising questions about why these Scots were so successful and why they faced so little native opposition. That process of segmented assimilation offers an insight into the formation of Britain and the shifting ground of national identity associated with the emerging British state. The Scots, moreover, provide a model for "successful" migration, suggesting that a range of factors - principally, an educated, culturally malleable, and economically responsive migrant population, alongside an institutionally and attitudinally flexible host community — need to be in place in order to optimize the chances of migrant assimilation.
\end{abstract}

The noblest prospect which a Scotchman ever sees, is the high road that leads him to England. -Samuel Johnson ${ }^{1}$

\section{INTRODUCTION}

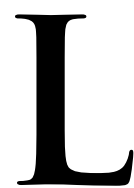

arge-scale migration and reaction to it are among the most contentious issues in contemporary Europe and North America. The literature on the subject is expansive, exploring why and how people move and what the consequences are for the places they leave and the places in which they settle. Historians too have long studied the movements of peoples whether in the context of the

Keith M. Brown is professor of history at the University of Manchester. Allan Kennedy is lecturer in history at the University of Dundee. The authors thank Professor Hannah Barker, University of Manchester; Professor Alice Bloch, University of Manchester; Professor Mike Braddick, University of Sheffield; Dr. Andrew Mackillop, University of Glasgow; and the anonymous referees for their helpful comments on earlier versions of this paper. Please direct any correspondence to keith.brown@manchester.ac.uk.

${ }^{1}$ James Boswell, Boswell's London Journal, 1762-1763, ed. Frederick A. Pottle (Edinburgh, 1991), 294. 
"barbarian" invasions of earlier eras, colonialism, or the refugee crises and economic migrations of recent history. Thus, in contrast to a stable ethnic, political, and cultural view of Britain with its indigenous Anglo-Saxon and Celtic peoples, it has become possible to offer a version of British history based on a narrative of waves of new arrivals being absorbed into the population and refashioning the culture and identity of those "natives." In addition, historians have challenged the idea of preindustrial society as composed of populations that were born, lived, and died largely in the same locality. While there are limits to how far such revisionism can be pushed, the value of historical studies in understanding migration can be significant in providing a perspective that goes beyond the more immediate concerns of contemporary studies, which are often informed by political and ideological positioning on the effects and desirability of modern mass migration.

The Scottish diaspora has enjoyed particular prominence in recent research into the history of British migrations. Public awareness has grown in line with the postdevolution drive to promote awareness of Scotland in the world, sustained by such high-profile initiatives as Tartan Day in the United States (now expanded into "Scottish Week") or the 2009 and 2014 Years of Homecoming. By contrast, academic interest in the diaspora evolved out of migration studies, economic history, and international history. Historians of the early modern period initially pursued an Atlanticfocused set of questions associated with Scottish migration to Ireland and North America, a discussion set within wider debates about colonialism and empire, which was in due course pulled through into the British imperial story of Scots in the Caribbean, India, and elsewhere. ${ }^{2}$ A different, European-facing discussion grew out of an avowedly non-Anglocentric approach that followed the diaspora across the North Sea, uncovering a rich story of Scottish migration throughout the north of the Continent and making visible a picture of complex networks, formed predominantly by trade and war, between migrants and their families and friends in Scotland. ${ }^{3}$

Capturing the scale of early modern migration is challenging because of deficiencies in the sources, creating considerable methodological problems for carrying out detailed longitudinal studies before the latter half of the eighteenth century and rendering historians' estimates tenuous. ${ }^{4}$ Scotland's population rose from about one million in the early seventeenth century to roughly 1.4 million by the middle of the eighteenth century. ${ }^{5}$ For the seventeenth century, the suggested numbers of emigrants range widely between 164,000 and 242,000, with Ireland being the most common destination, Poland and Scandinavia staying popular until mid-century, and America emerging as an important destination around 1650. During the first

\footnotetext{
${ }^{2}$ Although there were some indications of academic interest in Scottish diaspora studies in the 1960s, the historiography began to expand in the 1980s and has since built on the work of such scholars as T. M. Devine, Eric Richards, Marjory Harper, Steve Murdoch, Tanja Bueltmann, and many others. For a useful overview of the topic and its associated literature, albeit devoid of theoretical framing, see T. M. Devine, Scotland's Empire, 1600-1815 (London, 2003).

${ }^{3}$ Alexia Grosjean and Steve Murdoch, eds., Scottish Communities Abroad in the Early Modern Period (Leiden, 2005).

${ }^{4}$ Colin Pooley and Jean Turnbull, Migration and Mobility in Britain since the 18th Century (London, 1998), 319-20.

${ }^{5}$ Michael Anderson, "The Demographic Factor," in The Oxford Handbook of Modern Scottish History, ed. T. M. Devine and Jenny Wormald (Oxford, 2014), 39-61, at 39-44.
} 
half of the eighteenth century, the focus shifted decisively in favor of America; the majority of the 75,000 to 80,000 Scots estimated to have emigrated between 1700 and 1780 are reckoned to have gone there. ${ }^{6}$ These figures are speculative, but large numbers of Scots were unquestionably on the move at this time, with an especially high level of domestic population movement. ${ }^{7}$ Mobility, including over significant distances, was part of the normal range of choices open to people, and not for nothing did Tobias Smollett, the eighteenth-century Scottish writer, refer to "the disposition of the Scots, addicted to travelling."

A significant blind spot in this research is Scottish migration to early modern England. ${ }^{9}$ Historians of England with an interest in immigrant communities have ignored the Scots, being more concerned with exotic and easily identifiable European (particularly French Huguenot) migrants. ${ }^{10}$ What little attention the issue of Scottish immigration has received has come largely from scholars focusing on political elites-a group that, though a source of qualitative evidence, can tell us little about the scale of migration or the wider range of migration experiences. ${ }^{11}$ This historiographical gap is especially curious because the received narrative of Anglo-Scottish relations after 1603 makes the question of population exchange salient. ${ }^{12}$ The accession of James VI to the English throne as James I in 1603 created a new political context, as underlined by the decision in Calvin's Case (1608) that all subjects of the king born after 1603 de facto had the rights of naturalized Englishmen. This environment allowed Scots to view England as a viable and

${ }^{6}$ T. C. Smout, Ned Landsman, and T. M. Devine, "Scottish Emigration in the C17th and C18th," in Europeans on the Move: Studies in European Migration, 1500-1800, ed. Nicholas Canny (Oxford, 1994), 76-112.

${ }^{7}$ A. A. Lovett, I. D. Whyte, and K. A. Whyte, "Poisson Regression Analysis and Migration Fields: The Example of the Apprenticeship Records of Edinburgh in the Seventeenth and Eighteenth Centuries," Transactions of the Institute of British Geographers, n.s. 10, no. 3 (1985): 317-32.

${ }^{8}$ Sebastian Mitchell, Visions of Britain, 1730-1830: Anglo-Scottish Writings and Representation (Basingstoke, 2013), 55.

9 Steve Murdoch, "Scotland, Europe and the English 'Missing Link," History Compass 5, no. 3 (May 2007): 890-913. Categorization might be one explanation for this oversight, since Scottish settlement in England might be viewed as internal movement and therefore qualitatively different from international migration. See, for example, Dudley L. Poston and Leon F. Bouvier, Population and Society: An Introduction to Demography (Cambridge, 2010), 166. Scotland's "near diaspora" is rather better understood for the modern period; see Tanja Bueltmann, Andrew Hinson, and Graeme Morton, The Scottish Diaspora (Edinburgh, 2013), 153-70.

${ }^{10}$ See, for example, Randolph Vigne and Charles Littleton, eds., From Strangers to Citizens: The Integration of Immigrant Communities in Britain, Ireland and Colonial America, 1550-1750 (Brighton, 2001); Nigel Goose and Liên Bich Luu, eds., Immigrants in Tudor and Early Stuart England (Brighton, 2005); Liên Bich Luu, Immigrants and the Industries of London, 1500-1700 (Aldershot, 2005).

${ }^{11}$ Keith M. Brown, "Aristocracy, Anglicization and the Court, 1603-38," Historical Journal 36, no. 3 (September 1993): 534-76; Keith M. Brown, "The Origins of a British Aristocracy: Integration and Its Limitations before the Treaty of Union," in Conquest and Union: Fashioning a British State, 14851725, ed. Steven G. Ellis and Sarah Barber (London, 1995), 222-49; Smout, Landsman, and Devine, "Scottish Emigration," 88-90; Paul Langford, "South Britons' Reception of North Britons, 17071820," in Anglo-Scottish Relations from 1603 to 1900, ed. T. C. Smout (Oxford, 2005), 144-69.

${ }^{12}$ There was, of course, an established tradition of Scottish migration to England during the Middle Ages, which took place within a context of cross-border hostility. See James A. Galloway and Ian Murray, "Scottish Migration to England, 1400-1560," Scottish Geographical Magazine 112, no. 1 (March 1996): 29-38; J. A. F. Thomson, "Scots in England in the Fifteenth Century" Scottish Historical Review 79, no. 1 (April 2000): 1-16. 
even attractive migrant destination. Later developments, including the horrified Scottish reaction to English proposals in 1705 that they be reclassified as aliens, the full integration of England and Scotland through the parliamentary union of 1707 (the last of several attempts to negotiate union), and Scottish partnership in Britain's imperial project throughout the eighteenth century, confirmed to Scots the value of their access to England and deepened the relationship. ${ }^{13}$ In light of this underlying political narrative, one might expect to see steadily rising levels of Scottish immigration after 1603; however, with the exception of some localized studies, particularly of London and the Newcastle area, historians have shied away from testing this intuitive assumption. ${ }^{14}$

The present article addresses this lacuna by surveying an aspect of Scottish migration to England in the seventeenth and much of the eighteenth centuries. Marked by the new political contexts outlined above, and bookended by the accession of a Scottish king and the appointment of a Scottish prime minister, this period was characterized by an increasing level of Scottish migration to England. The majority of it seems to have been uncontentious, with most documented migrants appearing, on the basis of a range of markers, to have opted for a form of assimilation. The following analysis is based upon a biographical dataset of around three thousand named Scottish migrants in England between 1603 and ca.1760, compiled by scouring a wide range of published sources, as well as targeted surveys of archival collections across England. It does not represent a complete census of Scottish migrants in this period (an unattainable goal), only those for whom some record has survived. Moreover, it is probably a small sample. Current estimates, referenced below, would imply roughly sixty thousand Scots in London in 1760, but the dataset under discussion here records only about 450 named individuals in the capital during that year. If these proportions are representative of the dataset as a wholeand they might easily not be, since the figure of sixty thousand is, as we show below, based on extrapolation from extremely limited data-it suggests that less than 1 percent of the Scottish migrant population has been captured. That is obviously a low base from which to draw emphatic conclusions, especially as it is weighted toward elites and skilled groups for whom there are more records. Nevertheless, it is possible to make observations about this subset of the migrant population, an approach that has a theoretical underpinning in the concept of "segmented assimilation." This framework recognizes that over the course of generations some parts of a migrant population are likely to assimilate successfully while others will face structural or institutional barriers. The result is a "segmented" immigrant population, with some blending easily with the host community and others, often the disadvantaged, remaining distinct. ${ }^{15}$ This dynamic is relevant in the case

${ }^{13}$ Brian P. Levack, Formation of the British State: England, Scotland and the Union, 1603-1707 (Oxford, 1987); Bruce Galloway, The Union of England and Scotland, 1603-1608 (Edinburgh, 1986); Allan I. Macinnes, Union and Empire: The Making of the United Kingdom in 1707 (Cambridge, 2007); Devine, Scotland's Empire.

${ }^{14}$ See, for example, Stana Nenadic, ed., Scots in London in the Eighteenth Century (Lewisburg, 2010); Andrew Burn, "Work and Society in Newcastle upon Tyne, c. 1600-1710" (PhD diss., University of Durham, 2014), chap. 3.

${ }^{15}$ Alejandro Portes and Min Zhou, "The New Second Generation: Segmented Assimilation and Its Variants," Annals of the American Academy of Political and Social Sciences 530 (November 1993): 74-96; Min 
of Scots in early modern England, although the evidence base for the period is much more difficult to interpret than is the case in modern and contemporary studies. Many of these migrants faced little opposition to their arrival, leaving them free to modify their identity and to choose from a selection of options from full assimilation to return migration. The sample of identifiable migrants includes a minority of poor or otherwise undesirable Scots who were unwelcome in England and whose experiences were less benign; this group, representing around 10 percent of the dataset, is addressed elsewhere. ${ }^{16}$ Whatever the precise proportion of Scottish migrants who underwent assimilation, this appears to have been the experience of the majority of those for whom there is any record. By contrast, evidence of barriers to assimilation is very limited. Behind the acceptance of these Scottish migrants by the host society were their competitive advantages over other immigrants arising from the political and legal context, the status and skills of the migrants, and the degree of preexisting cultural affinities. This process of relatively large-scale assimilation points to some conclusions about the making of Britain. Scots made an important contribution to England's growing economy, but with much of this talent being absorbed by London-a structural pattern that persisted beyond the early modern period. Moreover, it became possible for Scottish migrants to exchange their national identity for a range of other elastic options, whether "English," "British," or "North British."

\section{MAPPING MIGRATION}

The map of migration for several groups in early modern England, especially the French and the Dutch, is fairly complete. ${ }^{17}$ But where were the Scots? Following the late medieval pattern, after 1603 a significant proportion of Scottish migrants were clustered north of the Mersey-Humber line. Unsurprisingly, Scots were found at Berwick-upon-Tweed, the English town closest to Scotland; by 1639 it housed a sufficiently large Scottish community to make it sympathetic toward the expected Covenanter invasion during the First Bishops' War. ${ }^{18}$ Migration is most clearly traceable through apprentices, among whom there were 199 identifiable Scots between 1619 and 1778. The majority of these-89 percent-originated from the adjacent counties of Berwickshire, Roxburghshire, and the Lothians. ${ }^{19}$ This number is not especially large, but the pattern of migration over the period is of interest. There are no records of any Scots before 1619 and only five in the period up to 1642 (none between 1633 and 1642); ten Scots were apprenticed between 1642 and 1668, following which there was another hiatus to 1701; sixtyfour Scots apprentices appear in the records between 1701 and 1730; and 120

\footnotetext{
Zhou, "Segmented Assimilation: Issues, Controversies, and Recent Research on the New Second Generation," International Migration Review 31, no. 4 (December 1997): 975-1008.

${ }^{16}$ Keith M. Brown, Allan Kennedy, and Siobhan Talbott, "'Scots and Scabs from North-by-Tweed': Undesirable Scottish Migrants in Seventeenth- and Early Eighteenth-Century England,” working paper.

${ }^{17}$ Nigel Goose, "Immigrants in Tudor and Early Stuart England," in Goose and Luu, Immigrants in Tudor and Early Stuart England, 17-29.

${ }^{18}$ Steve Murdoch and Alexia Grosjean, Alexander Leslie and the Scottish General of the Thirty Years War, 1618-1648 (London, 2014), 100.

${ }^{19}$ Berwick Enrolments, BAA/B6/1-4, Berwick Record Office (hereafter BRO).
} 
Scots apprentices were taken on between 1730 and 1778. This pattern of early local activity, followed by an oscillating growth pattern later in the seventeenth century and then steady expansion in the eighteenth century, is suggestive of the growing impact of the parliamentary union on migration patterns. These records need not imply permanent settlement in the Berwick area, but for some Scots this was the case. William Anderson, son of a miller from Mordington, was apprenticed to Richard Knape, a burgess of Berwick in 1633. In June the following year, he and his father jointly purchased a tenement in the Castlegate area of Berwick, suggesting a high level of commitment to establishing William within the town. ${ }^{20}$

Investigations of Scottish migration to the northeast of England more broadly indicate a steady flow of migrants that shifted from being predominantly seasonal to becoming permanent. Some of these people had individual skills that were in demand, such as Robert Jardine, a freeman of the hammermen of Edinburgh, who was working as an armorer in Newcastle in $1613 .^{21}$ There were close similarities between the economies of northeast England and southeast Scotland, which were being reshaped within the parameters of a British economy with a single labor market and complementary occupational groups. ${ }^{22}$ Thus Scots found employment in the important coal, salt, and glass industries. By 1600 large numbers of Scottish colliers were already on Tyneside, a number that increased along with keelmen (for shipping coal), mariners, and female servants, a mix of permanent, semi-permanent, and seasonal migrants. ${ }^{23}$ This evidence is difficult to quantify meaningfully, but from a register of 341 Newcastle keelmen taken in 1740, it appears that 55 percent were Scots. ${ }^{24}$ Seasonal migration continued into the eighteenth century; for example, a report from 1712 explained that four hundred of the keelmen in Newcastle had gone home to Scotland, "wither they go always in the winter." 25 Other migrants made their living servicing this community-individuals like George Chrystie, who moved from outside Dundee to run an inn in Newcastle until his death in 1744. ${ }^{26}$ However, the evidence for movement to England's northwestern counties is thinner, due largely to the absence of an urban center like Newcastle with a high demand for labor (Liverpool and Manchester, two cities that would later attract Scottish attention, do not in this period yield evidence of substantial Scottish settlement). Many of those people who turned up in Cumberland or Westmorland were vagrants, although there are examples of less penurious migrants, including John Maxwell and William Muirhead, Scottish merchants who had their wills proved at Carlisle in 1740 and 1745 , respectively. ${ }^{27}$

\footnotetext{
${ }^{20}$ Berwick Enrolments, BBA/B6/1, fols. 343r, 366r, BRO.

${ }^{21}$ Incorporation of Hammermen of Edinburgh Minute Books, ED008/1/2, Edinburgh City Archives.

${ }^{22}$ Keith Wrightson, "Kindred and Adjoining Kingdoms: An English Perspective on the Social and Economic History of Early Modern Scotland," in Scottish Society, 1500-1800, ed. R. A. Houston and I. D. Whyte (Cambridge, 1989), 245-60.

${ }^{23}$ Burn, "Work and Society in Newcastle upon Tyne," chap. 3.

${ }^{24}$ Smout, Landsman, and Devine, "Scottish Emigration," 88-89. Unsurprisingly, these individuals have not been captured in our dataset, as they left no record.

${ }^{25}$ Quoted in Joseph M. Fewster, The Keelmen of Tyneside: Labour Organisation and Conflict in the NorthEast Coal Industry, 1600-1830 (Woodbridge, 2011), 3-4.

${ }^{26}$ Edinburgh Commissary Court, CC8/8/108/417, National Records of Scotland (hereafter NRS).

${ }^{27}$ Susan Dench, ed., Index to the Wills Proved in the Consistory Court of Carlisle, 1661-1750 (London, 1998), 183, 189.
} 
Elsewhere in England, evidence for Scots is meager and scattered. Ports are obvious places to look in an era when sea transport was so important, but only Bristol had significant Scottish settlement, including migrants with interests in the West Indies, many of whom returned from the Caribbean after going there from Scotland to seek their fortune. ${ }^{28}$ Other Scots ended up in random locations. At an unknown date, Robert Bowker made his way from his birthplace in Newton, Midlothian, to Manchester, where his sons were baptized at the cathedral church in 1639 and 1641, and where Robert was buried on 6 September 1653. Clearly, Bowker settled in Manchester and lived there for at least fourteen years, but the rest of his story remains hidden. ${ }^{29}$ Surveys of local records elsewhere suggest that Scots rarely penetrated some parts of England, including the Midlands, East Anglia, or Devon and Cornwall.

London sat at the center of the English migratory system and was the most obvious focus of Scottish settlement. ${ }^{30}$ In 1567, only sixty-seven Scots were reported to be in London, and there was only a handful on the eve of regal union. ${ }^{31}$ No reliable estimates exist as to the number of Scots living in London in the seventeenth century, but a sample of more than eight thousand indentured servants leaving London in the century after 1680 suggests that 6 percent of them were Scots, an estimate similar to the figure derived from a much smaller-scale study of those attending the Westminster General Dispensary in the 1770s. ${ }^{32}$ Going by the best estimates of early modern London's growing population, this figure implies perhaps 35,000 London Scots in 1700 and around 60,000 by 1750 , the vast majority leaving no trace in the sources. ${ }^{33}$ Such figures would give London the largest urban population of Scots after Edinburgh, but the estimates are extremely rough and derived from very limited data. However, even if their numbers cannot be reliably reconstructed, especially after 1707 the scale of the Scottish presence was such that more attention needs to be paid to the Scottish contribution to the city and to London within the narrative of Scottish history. ${ }^{34}$

Early theoretical work on migration predominantly developed an understanding of it as an economic activity, driven by the need to exploit opportunities lacking in native communities. ${ }^{35}$ In the case of Scotland, the applicability of this model is commonly explained within the narrative of a relatively poor, north-European country

${ }^{28}$ Douglas J. Hamilton, Scotland, the Caribbean and the Atlantic World, 1750-1820 (Manchester, 2005), 195-216.

${ }^{29}$ E. Axon, ed., The Registers of the Cathedral Church of Manchester: Christenings, Burials, and Weddings, 3 vols. (Cambridge, 1908-1949), 2:184, 206, 608, 617.

${ }^{30}$ E. A. Wrigley, "A Simple Model of London's Importance in Changing English Society and Economy," Past and Present 37, no 1 (July 1967): 41-63; John Patten, English Towns, 1500-1700 (Folkestone, 1978), 235-36.

${ }^{31}$ Charles Rogers, "Memoir and Poems of Sir Robert Aytoun," Transactions of the Royal Historical Society 1 (1872): 110 .

32 John Wareing, "Migration to London and Transatlantic Emigration of Indentured Servants, 16831775," Journal of Historical Geography 7, no. 4 (October 1981): 356-78, at 373; Jerry White, London in the Eighteenth Century: A Great and Monstrous Thing (London, 2012), 90.

${ }^{33}$ Wrigley, "Simple Model." See also Vanessa Harding, "The Population of London, 1550-1700: A Review of the Published Evidence," London Journal 15, no. 2 (1990): 111-28.

${ }^{34}$ White, London in the Eighteenth Century, 94-99.

${ }^{35}$ Everett S. Lee, "A Theory of Migration," in Migration, ed. J. A. Jackson (Cambridge, 1969), 282-97; John R. Harris and Michael P. Todaro, "Migration, Unemployment and Development: A Two-Sector 
with a marginal, undeveloped economy and limited opportunities. ${ }^{36}$ Sometimes migrants departed because they were poor and desperate, but even in times of famine and consequent high morbidity, there is little evidence of large numbers of Scottish poor entering England, or migrating elsewhere for that matter. ${ }^{37}$ More commonly, people went to England because they had the material resources and the necessary skills to be accepted by the host population. As suggested by the theory of "mobility capital," which seeks to predict the likely success of individual migrant experiences by tabulating a person's "assets, competences, or dispositions," these elite and skilled Scots were well-placed to assimilate into English society. ${ }^{38}$ They had skills that were in demand, skills that gave them the means to prosper south of the border.

Yet for all that they shared an aura of respectability denied to their poorer or more troublesome countrymen, "desirable" Scottish migrants were not a homogenous group, being differentiated by rank and occupation and including unskilled labor. Many Scottish nobles followed James VI and I to London in 1603, some settling in England, so that over time dynasties such as the first three dukes of Argyll developed into an embryonic "British" elite as comfortable mixing in London society as tending to their Scottish estates. ${ }^{39}$ In the case of the Johnstones of Westerkirk, a qualitative picture has been constructed, demonstrating how a minor landed house spread out from Eskdale to England and Britain's growing imperial possessions in the Caribbean, North America, and India. ${ }^{40}$ Furthermore, because of the structures of noble households, elites did not function without those who served them. For example, William Carswell, a Paisley man, died in London in 1738 while serving as tutor to the second earl of Forfar. ${ }^{41}$

Unlike other immigrants to England, from 1603 Scots had access to the highest political circles through the patronage networks headed by their own elites centered on the agencies of power at the royal court. ${ }^{42}$ Scottish elites obtained significant influence beyond their own country-John Maitland, duke of Lauderdale, for example, was part of the loose association of ministers usually known as the "Cabal," which dominated the court from 1667 until 1673, while securing a tight grip on Scottish policy nearly until his death in $1682 .{ }^{43}$ In the eighteenth century, the forty-five Scottish MPs and sixteen representative peers who attended the Westminster Parliament had opportunities to make their mark on London society. John Montgomerie, elected MP for Ayrshire in 1710, having previously been a soldier, became a friend of the future George II, through whose influence he was appointed

Analysis," American Economic Review 60, no. 1 (1970): 126-42; D. B. Grigg, "E. G. Ravenstein and the 'Laws of Migration," Journal of Historical Geography 3, no. 1 (January 1977): 41-54.

${ }^{36}$ Smout, Landsman, and Devine, "Scottish Emigration."

${ }^{37}$ Karen Cullen, Famine in Scotland: The 'Tll Years' of the 1690s (Edinburgh, 2010), 172-73.

${ }^{38}$ Joya Chatterji, "Disposition and Destinations: Refugee Agency and 'Mobility Capital' in the Bengal Diaspora, 1947-2007," Comparative Studies in Society and History 55, no. 2 (April 2013): 273-304, at 279.

39 Brown, "Aristocracy, Anglicization and the Court"; Brown, "Origins of a British Aristocracy," 247-49; John S. Shaw, The Management of Scottish Society, 1707-1764: Power, Nobles, Lawyers, Edinburgh Agents and English Influences (Edinburgh, 1983).

${ }^{40}$ Emma Rothschild, The Inner Life of Empires: An Eighteenth-Century History (Princeton, 2012).

${ }^{41}$ CC8/8/101/253, NRS.

42 Brown, "Aristocracy, Anglicization and the Court"; Brown, "Origins of a British Aristocracy."

${ }^{43}$ Raymond Campbell Paterson, King Lauderdale: The Corruption of Power (Edinburgh, 2003). 
governor of New York in 1727.44 For the few Scots who managed to achieve it, securing election to a non-Scottish constituency was one of the clearest markers of successfully breaking into the English establishment. John Gibson, an Edinburgh soldier who rose to command William III's forces in Newfoundland in 1697, settled in Portsmouth after the Glorious Revolution, serving as its deputy lieutenant governor until his death in 1717. He represented the town at Westminster twice between 1696 and 1698 and briefly again in 1702.45 From an early stage in the regal union, Scots accessed offices in the wider governmental framework, national and local, though their numbers were small. For example, William Balfour, a former soldier who became a gentleman of the bedchamber to Charles I, was made lieutenant of the Tower of London in 1630.46 Some Scots combined military, colonial, and English office. Robert Hunter, a soldier who ended his military career in 1706 as an aide-de-camp to the duke of Marlborough, retired to London before exercising the office of governor of New York and New Jersey from 1710 to 1720. He returned to London for seven years, serving as comptroller of customs before becoming governor of Jamaica from 1727 to $1734 .{ }^{47}$

The early modern era, the eighteenth century in particular, was marked by the emergence of "professions," resulting in a marketplace within which skilled Scottish migrants with connections could penetrate English socioeconomic structures. ${ }^{48}$ The distinctions between the official churches, even though there were periods of ecclesiastical convergence, made it difficult for Scottish clerics to pursue careers in England. Some Episcopalian-minded Scots entered the Anglican Church, including Edinburgh-born Walter Balcanquhall, who was educated at Pembroke College, Cambridge, and was a devotee of the Church of England, enjoying a string of appointments from the Cambridgeshire vicarage of Harston in 1615 to the deanery of Durham in $1640 .{ }^{49}$ Balcanquhall's lifelong assimilation was unusual; most Scotsborn clerics who ended up in the Church of England did so after escaping religious strife. At least twenty Episcopalian clerics, including several bishops, settled in England in the aftermath of the Covenanting revolution that began in 1637. For example, William Annan, erstwhile minister of Ayr, became vicar of Selling in

${ }^{44}$ J. M. Simpson, s.v., "Montgomerie, John (1680-1731), of Giffen, Ayr," History of Parliament, accessed 21 June 2017, http://www.historyofparliamentonline.org/volume/1715-1754/member/ montgomerie-john-1680-1731.

${ }^{45}$ Paula Watson, s.v., "Gibson, John (c. 1637-1717), of Portsmouth, Hants.," History of Parliament Online, accessed 21 June 2017, http://www.historyofparliamentonline.org/volume/1690-1715/member/ gibson-john-1637-1717.

${ }^{46}$ Edward M. Furgol, s.v., "Balfour, Sir William (d. 1660)," Oxford Dictionary of National Biography (hereafter $O D N B$ ), accessed 11 August 2015, https://doi.org/10.1093/ref:odnb/1198.

${ }^{47}$ Mary Lou Lustig, s.v., "Hunter, Robert (1666-1734)," ODNB, accessed 11 August 2015, https:// doi.org/10.1093/ref:odnb/14228.

48 Stana Nenadic, "Architect-Builders in London and Edinburgh, c. 1750-1800, and the Market for Expertise," Historical Journal 55, no. 3 (September 2012): 597-617, at 600-1; Rosemary O'Day, "Social Change in the History of Education: Perspectives on the Emergence of Learned Professions in England, c. 1500-1800," History of Education 36, nos. 4-5 (July 2007): 409-28, at 412-15; Wilfred Prest, "Introduction: The Professions and Society in Early Modern England," in The Professions in Early Modern England, ed. Wilfred Prest (London, 1987), 1-24, at 6-17.

${ }^{49}$ John Coffey, s.v., "Balcanquhall, Walter (c. 1586-1645),” ODNB, accessed 11 August 2015, https:// doi.org/10.1093/ref:odnb/1151. 
Kent in 1639 and secured the vicarage of Throwley, also in Kent, ten years later. ${ }^{50}$ Comparable movement was evident following the revolution in 1688-69. Of the estimated one hundred Scots clergy who fled to England in this period in search of refuge as much as opportunity, several ended up in the Church of England, including John Macmath, former minister of Rathos and Dalkeith, who was appointed to the parish of Grays in Essex in 1692. ${ }^{51}$

While opportunities within the Church of England were limited, Scots clergy were found ministering to dissenting Presbyterian congregations. Indeed, in some localities, Scottish-born ministers predominated, especially in the northwest, such as at Brampton, Cumberland, where a continuous succession of six Scots served between ca. 1709 and $1772 .{ }^{52}$ The clearest opportunities were to be found in congregations affiliated with the Church of Scotland, such as the "Low Meeting," which existed at Berwick-upon-Tweed from at least 1686, when William Forster, probably a Scot, was named as its minister. ${ }^{53}$ London had two Scots Presbyterian congregations in 1657, one at Blackfriars and one at Scotch Hall. Nothing further is known about these churches, but during the following decade the first verifiable Scots church emerged at Founders' Hall in Lothbury. Another Scottish congregation emerged at Swallow Street, created before 1709 and originally meeting on Glasshouse Street, and a third was founded in 1711 at Crown Court-although the Scottishness of this last, which described itself in 1714 simply as a "Congregation of Protestant Desenters," can be questioned. ${ }^{54}$ Unsurprisingly, Scots frequently ministered to these charges, the earliest known minister at Founders' Hall being Edinburgh-born Alexander Carmichael, called in 1672, with four other Scottish ministers arriving in $1684,1698,1729$, and $1751 .{ }^{55}$ Aside from the Scots congregations, London housed several English Presbyterian congregations to which Scottish ministers were occasionally called, including John Grant, working at a meetinghouse in Ealing in the early 1730s. ${ }^{56}$

In contrast to ecclesiastical office, the legal profession offered few opportunities. The barriers to Scots practicing law in England were considerable because of the distinct legal systems, with Scotland drawing heavily upon Roman law, while in England common law was emphasized. ${ }^{57}$ Furthermore, England was thought to be over-provided with lawyers. ${ }^{58}$ Consequently, only a handful of Scots practiced

${ }^{50}$ Hew Scott, Fasti Ecclesiae Scoticanae: The Succession of Ministers in the Church of Scotland from the Reformation, 7 vols. (Edinburgh, 1915-28), 1:165-6, 3:8-9, 7:334.

${ }^{51}$ Ibid., 1:329.

52 Ibid., 2:156, 175, 266, 313, 494; 7:468, 483, 494, 512.

${ }^{53}$ Quarter Session Minutes 1694-1726, no pagination [27 July 1686], BBC/C8/1, BRO.

${ }^{54}$ George G. Cameron, The Scots Kirk in London (Oxford, 1979), 18-25, 43-46; Minutes of Crown Court Kirk Session, 1711-46, CH2/852/1, p. 52, NRS

${ }^{55}$ Scott, Fasti, 7:489-90; Register of the Scots Kirk, London Wall, 1716-1773, CLC/182/04962, 25867, 278-80, London Metropolitan Archives (hereafter LMA). For Scottish ministers at Swallow Street and Crown Court churches, see Scott, Fasti, 7:267-71, 500

${ }^{56} \mathrm{CC} 8 / 8 / 95 / 304$, NRS.

${ }^{57}$ J. H. Baker, An Introduction to English Legal History, 4th ed. (London, 2002), 162-64; Wilfred Prest, "The English Bar, 1550-1700," in Lawyers in Early Modern Europe and America, ed. Wilfred Prest (London, 1981), 65-85, at 77-81; Daniel Duman, "The English Bar in the Georgian Era," in Lawyers, 86-107; William M. Gordon, "A Comparison of the Influence of Roman Law in England and Scotland," in Gordon, Roman Law, Scots Law and Legal History: Selected Essays (Edinburgh, 2007), 309-23.

${ }^{58}$ Duman, "English Bar," at 89. 
in England, men like the obscure Mr. Johnson who was described in 1639 as a "councellor at law dwellinge in black fryers." 59 Edinburgh-born William Hamilton moved to London shortly after the parliamentary union, was called to the bar, created a bencher at Lincoln's Inn, and ultimately earned Horace Walpole's withering judgment that he was "the first Scot who ever pleaded at the English bar, and it was said of him, should have been the last." 60 He was not, but numbers remained paltry. Among them, however, was the striking success story of William Murray, earl of Mansfield, who was educated in England, pursued a legal career there, and was appointed chief justice of the king's bench in 1756. Crucially, perhaps, Mansfield left Scotland in 1719 for Westminster School at the age of fourteen; hence Samuel Johnson's jibe in relation to him that "much may be made of a Scotchman if he be caught young."61 Here lay the origins of a process by which higher-ranked and wealthier Scots found entry to the emerging British elite through the English public-school system.

In the medical professions, Scots were more numerous. Walter Rosse, a surgeon attached to the Covenanting armies, briefly settled in Manchester in the late 1640s, although he was forced home by the Commonwealth regime in 1651.62 Robert Richardson, likely from Edinburgh, was working as a physician in Leeds when he was made executor of his brother's will in 1720.63 These scattered examples demonstrate that Scottish medical men turned up throughout England, but the majority ended up in London. ${ }^{64}$ At least twenty-four Scots were admitted to the Royal College of Physicians in this period, either as fellows, licentiates, or extra-licentiates. These medics, often benefiting from the sophisticated medical education available in Scottish universities and drawing upon the patronage and support of other Scots, made their presence felt especially strongly after the Glorious Revolution. One of these was Aberdeen-born David Gregory, better known as a mathematician and, after 1691, professor of astronomy at Oxford, but who also practiced medicine. Gregory's patronage allowed several of his pupils to break into London medicine, including John Arbuthnot, who attended Prince George of Denmark in the 1700s and became a royal physician to Queen Anne. ${ }^{65}$ A further spasm of medical migration to London took place in the 1720s and 1730s. Among the Scots moving south, one of the best known was Aberdeen-born Charles Maitland; as a surgeon attached to the British embassy in Constantinople, in 1721 he carried out the first smallpox inoculation in England on the ambassador's daughter. ${ }^{66}$ 85.

59 The National Archives (hereafter TNA), State Papers Domestic: Charles I, SP16/418, fol. 184, item

${ }^{60}$ Horace Walpole, Memoirs of the Last Ten Years of the Reign of George II, 2 vols. (London, 1822), 1:402.

${ }^{61}$ James Oldham, s.v., "Murray, William, first earl of Mansfield (1705-1793)," ODNB, accessed 11 August 2015, https://doi.org/10.1093/ref:odnb/19655.

${ }_{62}$ Quarter Session Petitions, QSP/52/14, Lancashire Archives.

${ }^{63} \mathrm{CC} 8 / 8 / 87 / 658$, NRS.

${ }^{64}$ From the later eighteenth century, Scottish surgeons began to develop a notable presence in Liverpool, largely through connections with the slave trade. Suzanne Schwarz, "Scottish Surgeons in the Liverpool Slave Trade in the Late Eighteenth and Nineteenth Centuries," in Recovering Scotland's Slavery Past: The Caribbean Connection, ed. T. M. Devine (Edinburgh, 2015), 145-65.

${ }^{65}$ J. H. McCulloch, The Scot in England (London, 1935), 49.

${ }^{66}$ Anita Guerrini, "Scots in London Medicine in the Early Eighteenth Century," in Nenadic, Scots in London, 165-85. 
Scots made a particular contribution to the development of man-midwifery. William Smellie started out as an apothecary in Lanark, developed an interest in midwifery, and moved to London in 1740, where he established a practice specializing in difficult births assisted by the use of forceps. He set up as a teacher, instructing hundreds of pupils before his retirement back to Lanark in 1759; his Treatise on the Theory and Practice of Midwifery (1751) became the standard text on the subject. His pupil, the East Kilbride-born William Hunter, was a prolific teacher and writer in the capital; Hunter's specialization in august clientele, up to and including George III's wife, Queen Charlotte, stimulated him to develop a more anti-interventionist approach to obstetrics. ${ }^{67}$ Nevertheless, in spite of the influence of a few highprofile Scottish physicians, the number of practitioners working in England was modest, with just over one hundred being identified.

Artists of various types took the road from Scotland to England. James VI's Scottish court was well-served by poets, and after 1603 a few Scots joined him in London, including Sir Robert Ayton, who became secretary to Queen Anna in 1612, as well as serving as a diplomat and being buried in Westminster Abbey. ${ }^{68}$ However, these figures were peripheral to court culture. Toward the end of the seventeenth century, a group of Scottish political controversialists was active in London, including Robert Ferguson, nicknamed "the plotter"; 69 the antiquarian and historian James Anderson; ${ }^{70}$ and Berwickshire-born George Ridpath, a prominent writer and pamphleteer throughout the 1690s and 1700s, described by the Dutch Gazeteer as "one of the best pens in England."71 Probably the most celebrated Scottish author in eighteenth-century London was Tobias Smollett, who first settled there in 1739, aged eighteen, and after a period in the Royal Navy, made London his home in 1744. Two years later, he published The Adventures of Roderick Random and went on to achieve great literary fame. ${ }^{72}$

Opportunities existed for low-paid and itinerant musicians, and although most such individuals probably went unrecorded, a few Scots can be identified-men like George Michell, ejected as a vagrant from Salisbury in 1606 after being caught "vsing a kind of playe vppon bones and bells."73 More visible musicians found a niche performing Scottish-inspired works. William Thomson sang publicly in Scotland before moving to London around 1722, where he performed traditional Scottish songs for George I, circulating some of them in published compendia. ${ }^{74}$

\footnotetext{
${ }^{67}$ Adrian Wilson, The Making of Man-Midwifery: Childbirth in England, 1660-1770 (London, 1995), 123-31, 175-82.

${ }^{68}$ Harriet Harvey Wood, s.v., "Ayton, Sir Robert (1570-1638)," ODNB, accessed 11 August 2015, https//doi.org/10.1093/ref:odnb/958.

${ }_{69}$ Melinda Zook, s.v., "Ferguson, Robert (d. 1714)," ODNB, accessed 11 August 2015, https://doi.org/ 10.1093/ref:odnb/9325.

${ }^{70}$ Alexander Du Toit, s.v., "Anderson, James (1662-1728)," ODNB, accessed 11 August 2015, https:// doi.org/10.1093/ref:odnb/473.

${ }^{71}$ G. A. Aitkin, rev. John R. Young, s.v., "Ridpath, George (d. 1726),” ODNB, accessed 11 August 2015, https://doi.org/10.1093/ref:odnb/23635.

72 Jeremy Lewis, Tobias Smollett (London, 2003), 22-50, 87-89, 136-41, 184, 209-21; Kenneth Simpson, s.v., "Smollett, Tobias George (1721-1771)," ODNB, accessed 11 August 2015, https://doi. org/10.1093/ref:odnb/25947; Robert Donald Spector, Tobias George Smollett (Boston, 1989), 1-23.

${ }^{73}$ Salisbury City Council Poor Relief Records, G23/1/228, Wiltshire and Swindon Archives.

${ }^{74}$ Mary Anne Alburger, "Musical Scots and Scottish Musical Patrons on London and Edinburgh," in Nenadic, Scots in London, 186-203, at 188-89.
} 
Among the Scottish painters who gravitated to London was Allan Ramsay, who arrived in the capital in 1738, becoming the most celebrated portrait painter in mid-eighteenth century Britain. Ramsay, like other prominent Scottish artists active in late Stuart and Hanoverian London, relied initially upon the patronage and support of other Scots, benefiting from a close personal relationship with John Stuart, third earl of Bute and prime minister. ${ }^{75}$

It was in architecture, however, that Scots made their most significant and visible creative contributions to early modern England. Both Aberdeen-born James Gibbs, known for Oxford's Radcliffe Library, and his bitter rival, Colen Campbell from Nairnshire, renovator of Burlington House, Piccadilly, grew rich and famous as exponents of the palladian style. ${ }^{76}$ By the mid-eighteenth century, palladianism had given way to grander neoclassical tastes, and here too Scottish architects were prominent. Robert Adam, who moved to London in 1758 after a successful career in Scotland, was renowned for his work on country houses such as Osterley Park and Syon House, both in Middlesex. Adam's principal rival in London was another Scot, William Chambers, best known for redesigning Kew Gardens and for his work on Somerset House. ${ }^{77}$ What these examples appear to suggest is that while Scotland lacked the resources to hold onto much of its best talent, it had a sufficiently dynamic construction and design sector to generate skills and contribute toward the physical interpretation of Britain at the heart of empire.

Considering the extravagant claims often made about Scotland's educational system, the number of Scottish educationalists in England was very low. Among the handful known is James Chambers, who was given a year's contract at the grammar school in Hull in October $1627 .{ }^{78}$ Others worked as tutors, most famously the Perthshire-born poet David Mallet, who arrived in London in 1723 as tutor to the children of the first duke of Montrose, a position he retained until 1732 (thereafter finding work with the Essex gentleman John Knight) and from which he launched a career as a poet and propagandist. ${ }^{79}$ At a higher level, a few Scots acquired chairs in English universities. David Gregory held the Savilian chair of astronomy at Oxford from 1691 until his death at London in $1708 .{ }^{80}$ His student John Keill

${ }^{75}$ David Irwin and Francina Irwin, Scottish Painters at Home and Abroad, 1700-1900 (London, 1975), 41-47, 51-64, 101-5; Duncan Macmillan, Painting in Scotland: The Golden Age (Oxford, 1986), 9-30, 32-41; Patricia A. Andrew, "Scottish Artists in London: Careers and Connections," in Nenadic, Scots in London, 204-28.

${ }^{76}$ Terry Friedman, James Gibbs (New Haven, 1984), 7-20; Peter Kidson, Peter Murray, and Paul Thompson, A History of English Architecture (London, 1979), 213-15, 217-19, 222-24; T. P. Conner, "Colen Campbell as Architect to the Prince of Wales," Architectural History 22 (1979): 64-71.

${ }^{77}$ Frank Hoar, An Introduction to English Architecture (London, 1963), 140-46; Kidson, History of English Architecture, 233-51; Nenadic, "Architect-Builders"; Margaret H. B. Sanderson, Robert Adam and Scotland: Portrait of an Architect (Edinburgh, 1992), 53-66; David Watkin, English Architecture: A Concise History (London, 1979), 131-36.

${ }^{78}$ Bench Book V (1609-1650), U DX/5/8, fol. 57, Hull History Centre.

79 Sandro Jung, David Mallet, Anglo-Scot: Poetry, Patronage and Politics in the Age of Union (Newark, 2008), 24-54, 76-111,127-59.

${ }^{80}$ Anita Guerrini, "The Tory Newtonians: Gregory, Pitcairne, and Their Circle," Journal of British Studies 25, no. 3 (July 1986): 288-311; Anita Guerrini, s.v., "Gregory, David (1659-1708)," ODNB, accessed 11 August 2015, https://doi.org/10.1093/ref:odnb/11456. 
lectured in experimental and natural philosophy at Oxford and was elected to the same Savilian chair in 1712.81

Scottish trade networks in and through England were already well founded by the time of the parliamentary union. ${ }^{82}$ One of the first merchants to gain a footing in London was the Edinburgh goldsmith and creditor of James VI, George Heriot, who set up business in the city in $1603 .{ }^{83}$ Most trade activity was concentrated in London, and an insight into the nature of Scottish networks in the capital can be gleaned from the business diary of William Fraser, which covers the period 1699 to 1711. Fraser acted as an agent, buying Scottish goods to sell in London or overseas, while shipping other products, often exotics from across the empire, back to his mercantile contacts at home. Fraser invested some of his profits into property in England; by 1700 he controlled a number of houses in Red Lion Fields, Holborn, Stepney, Shoemakers Row, and Princes Street, while also managing his Scottish estate of Pitcalzean in Ross-shire. ${ }^{84}$ Opportunities of this kind grew after 1707 . Alexander Grant, born in Inverness-shire in 1705, came to London in 1739 after a long spell as a physician in Jamaica. He joined with another London Scot, the druggist Alexander Johnston, establishing himself as a sugar merchant, acting as agent for the Grant family, and cultivating friendships with other powerful London Scots. Grant, who was elected MP for the Inverness burghs in 1761, bought several estates along the Moray coast but preferred to reside in London and in his country villa at Brookham Grove in Surrey. ${ }^{85}$

However, Scottish mercantile interests were not wholly restricted to the capital. At least twenty-four Scots were apprenticed to merchants in Berwick-upon-Tweed between 1710 and 1772, while another six mercantile apprentices are known to have enrolled at Newcastle between 1707 and 1741. ${ }^{86}$ James Smith was based in Leicester prior to proving his will at Dumfries in 1742, and John Mullyan was a linen trader in Liverpool by $1760 .{ }^{87}$ The most promising center of Scottish mercantile interest outside London was Bristol, where Scots worked their way into the merchant elite of the city, using their West Indies profits to set themselves up there while retaining strong links with their home country. ${ }^{88}$

Scotland had a long history of exporting soldiers, a tradition that continued throughout the seventeenth century, and it was only from the 1690s that the majority

\footnotetext{
${ }^{81}$ Guerrini, “Tory Newtonians," 293, 309; John Henry, s.v., "Keill, John (1671-1721)," ODNB, accessed 11 August 2015, https://doi.org/10.1093/ref:odnb/15256.

82 T. C. Smout, Scottish Trade on the Eve of Union, 1660-1707 (Edinburgh, 1963); Siobhan Talbott, Conflict, Commerce and Anglo-Scottish Relations (London, 2014); Steve Murdoch, Network North: Scottish Kin, Commercial and Covert Associations in Northern Europe, 1603-1746 (Leiden, 2006), 243-4; Macinnes, Union and Empire.

${ }^{83}$ McCulloch, Scot in England, 38-40.

${ }^{84}$ Journal of William Fraser, CS96/524, NRS.

${ }^{85}$ David Hancock, Citizens of the World: London Merchants and the Integration of the British Atlantic Community, 1735-1785 (Cambridge, 1995), 48-59.

${ }^{86} \mathrm{BBA} / \mathrm{B} 6 / 1-4$, BRO; Company Book of the Incorporated Company of Merchant Venturers, 16751733, GU.MA/2/1, fols. 29v, 291, 299, 320, 327, Tyne and Wear Archives (hereafter TWA).

${ }^{87}$ CC5/6/11/358, NRS; J. Arrowsmith et al., eds., The Registers of the Parish of Ormskirk, 3 vols. (Rochdale, Macclesfield, and Bristol, 1902-2009), 3:227.

${ }^{88}$ Hamilton, Scotland, the Caribbean and the Atlantic World, 212-14.
} 
of Scots in military service were recruited by the crown. ${ }^{89}$ Soldiers and sailors included men recruited as officers from the highest ranks to men drawn from the dregs of society, but whatever their rank, there were no barriers to Scots within the military. It was a Scot, Patrick Ruthven, whom Charles I placed in command of his army at the outset of the English Civil War, and over the course of the seventeenth century Scottish officers and regiments were employed in the English armed forces. ${ }^{90}$ Especially after 1707, Scots were overrepresented among the higher ranks of the army, where about a quarter of the officer corps was Scottish; one-fifth of the roughly 370 new colonelcies created between 1714 and 1763 were secured by Scots. ${ }^{91}$ Of the common soldiery we know much less, but Scots served in great numbers. At one per every 450 residents by 1770, Scotland had the highest density of Chelsea pensioners anywhere in the British Isles. ${ }^{92}$ Highlanders in particular found niches as warriors of empire, especially in the decades after the final defeat of Jacobitism in 1745-46. During the Seven Years' War (1756-63), the first to be marked by large-scale Highland recruitment, an estimated twelve thousand Highlanders served. ${ }^{93}$ Service in the army did not necessarily imply residence in England, but some men chose to settle there, including William Ker, a captain resident in London who served as master of the Royal Scottish Corporation in 16991700. ${ }^{94}$ For others, however, it was difficult to make a home in England. In 1734, John Mccloud, a disbanded soldier who attempted to make a living as a travelling seller of "ballads pins and needles," was apprehended as a vagrant at Thirsk and sent back to Scotland. ${ }^{95}$

A Scottish presence in the English maritime community can be measured from the early seventeenth century, gathering pace with the rapid expansion of the Royal Navy after 1688. ${ }^{96}$ Scots encountered little difficulty in penetrating the officer corps. Among the most spectacular success stories was David Mitchell, an Aberdeen-born "poor boy" who was pressed into the navy in 1673, eventually becoming lord high admiral in $1702 .{ }^{97}$ Ordinary seamen, whether employed in the navy or on trade vessels, are more difficult to trace. Some appear randomly in unexpected places. We only know about Inverness-born John Howard, who became a sailor around 1714 and served for more than twenty-five years, because he turned up as

${ }^{89}$ John Hayes, "Scottish Officers in the British Army, 1714-1763," Scottish Historical Review 37, no. 123 (April 1958): 23-33; Keith M. Brown, "From Scottish Lords to British Officers: State Building, Elite Integration, and the Army in the Seventeenth Century," in Scotland and War AD79-1918, ed. Norman Macdougall (Edinburgh, 1991), 133-69.

${ }^{90}$ Murdoch and Grosjean, Alexander Leslie, 121-24.

${ }^{91}$ Hayes, "Scottish Officers," at 26.

92 Andrew MacKillop, "More Fruitful than the Soil": Army, Empire and the Scottish Highlands, 1715-1815 (East Linton, 2000), 246.

${ }^{93}$ Ibid., 236; Devine, Scotland's Empire, 304-15; Robert Clyde, From Rebel to Hero: The Image of the Highlander, 1745-1830 (East Linton, 1995), 150-77.

${ }_{94}$ Original Design, Progress and Present State of the Scots Corporation at London (London, 1730).

${ }^{95}$ Quarter Sessions: Register of Vagrants, 1740-1852, QDV, North Yorkshire County Record Office.

${ }^{96}$ Andrew Little, "A Comparative Survey of Scottish Service in the English and Dutch Maritime Communities c. 1650-1707," in Scottish Communities Abroad, 333-74; Steve Murdoch, The Terror of the Seas: Scottish Maritime Warfare, 1513-1713 (Leiden, 2010).

${ }^{97}$ John B. Hattendorf, s.v., "Mitchell, Sir David (c. 1650-1710)," ODNB, accessed 11 August 2015, https://doi.org/10.1093/ref:odnb/18836. 
a vagrant in Kirkleatham following his discharge in $1741 .^{98}$ Surviving ship manifests contain more extensive information, and analysis of Bristol muster rolls between 1748 and 1762 reveals a total of 107 Scottish sailors working in the triangular slave trade between England, Africa, and America. Some of these men, such as Richard Holden, who served on at least four different ships between 1749 and 1757, were veterans of the Bristolian slave trade and presumably settled in the West Country.99 The best evidence for ordinary seamen is their wills, often drafted in anticipation of a hazardous voyage. Between 1690 and 1750, twenty-five sailors' wills were registered at the Canterbury Court of Probate by individuals from Angus alone. ${ }^{100}$ In instances like these, it is uncertain whether a naval career implied a long-term presence in England, although sometimes it did, usually in London's maritime quarters. Thus, John Gatty, from Aberdeen, named as his executrix in 1691 Martha Green, his landlady in Stepney, suggesting some degree of residence there. ${ }^{101}$

Outside of the professions, the mercantile elite, and the military, other occupational groupings are difficult to trace. Probate records offer tantalizing insights into individual lives. For example, Jeane Trotter's will, proved at Edinburgh in August 1635, makes reference to the fact that she was the widow of Hew Leith, a Scottish tailor who had died in London some years earlier. ${ }^{102}$ Apprenticeship registers point to a cluster of Scottish apprentices in eighteenth-century Newcastle, men like Walter Scott from Girnwood, apprenticed as a joiner in 1711, or John Cameron, originally from Inverlochy but enrolled as an apprentice smith in $1730 .{ }^{103}$ More substantial evidence comes from Berwick's 199 Scottish apprentices. Of these, the biggest proportion, 25 percent, were apprenticed to coopers, but a great many other specialists were represented, including merchants, carpenters, shoemakers, and tailors. ${ }^{104}$ At least 266 Scots registered with London companies during the period under study, representing fifty-six occupations. The largest numbers of apprentices were drawn to textile work, so that cloth-workers, drapers, and feltmakers between them make up approximately one-fifth of the sample. Where a point of origin can be identified, most of these young men came from the larger Scottish towns, particularly Edinburgh ( 23 percent), Aberdeen ( 6 percent), and Glasgow (3 percent), but at least one apprentice can be shown to have arrived in London from each of twenty-seven Scottish counties, from Wigtownshire to Caithness, providing evidence that London drew in Scots from a wide range of localities. ${ }^{105}$

${ }^{98}$ Register of Vagrants, QDV, North Yorkshire County Record Office.

${ }^{99}$ Ships' Muster Rolls, 1748-1762, SMV/9/3/1, Bristol Record Office.

${ }_{100}$ Andrew MacKillop, "Dundee, London and the Empire in Asia," in Dundee: Renaissance to Enlightenment, ed. Charles McKean, Bob Harris, and Christopher A. Whatley (Dundee, 2009), 166.

${ }^{101}$ MS9172/80, Will 65, Guildhall Library.

102 CC8/8/57/352, NRS.

103 TNA, Board of Stamps: Apprenticeship Books, IR/1/41, fol. 122; Company of Smiths: Apprentice Indentures, 1600-1877, GU.SM/36/1, TWA.

${ }^{104} \mathrm{BBA} / \mathrm{B} 6 / 1-4, \mathrm{BRO}$.

105 The sample is derived from D. F. McKenzie, ed., Stationers' Company Apprentices, 1641-1700 (Oxford, 1974); Cliff Webb, ed., London Livery Company Apprenticeship Registers, 48 vols. (London, 1996-2008); Records of London's Livery Companies Online, www.londonroll.org. These data are supplemented from Tim Hitchcock et al., eds., The Old Bailey Proceedings Online, 1674-1913, www.oldbaileyonline.org; Tim Hitchcock et al., eds., London Lives, 1690-1800, www.londonlives.org, version 1.1, 24 April 2012; TNA, IR/1. 
On the whole, Scots women were in England because of their fathers or husbands, with only a few women migrating on their own. Margaret Kerr, whose will was proved at Edinburgh in July 1729, was the daughter of John Kerr of Blackburn, and appears to have married an Englishman, George Clark, a miller, and lived in the Newcastle area where she died. ${ }^{106}$ Janet Mawer, from Lochgelly in Fife, lived with her husband, a keelman, at Newcastle, where she died some time before November 1749, ${ }^{107}$ and Marion Melvill, who died in London a decade later, was married to a London butcher. ${ }^{108}$ Male agency was not always apparent, however; there is nothing to suggest that nineteen-year-old Helen Forrest, from Edinburgh, was following a male relative when she entered employment as a domestic servant in London in 1720.109 A large proportion of the women appear on records as vagrants, often because they had been widowed, but this was not always the case. Hanna Limant was a nineteen-year-old Scottish woman detained in 1756 at Norwich for vagrancy which, she said, she resorted to after suffering a debilitating illness, but there is no record of what brought her to England. ${ }^{110}$ Similarly, thirtysix year-old Sarah Little, arrested in Morland, Westmorland, and served with a removal order, does not appear to have been associated with a man, and no mention is made of widowhood. ${ }^{111}$

\section{ASSIMILATION}

The foregoing discussion makes it clear that a wide variety of elite, skilled, and even unskilled Scots settled in England in the seventeenth and eighteenth centuries; some even secured significant social and economic positions in their adoptive country. By contrast, most other skilled migrant populations in early modern England were much less pervasive. Aside from a smattering of musicians attracted by royal patronage, German immigrants were overwhelmingly merchants, often specializing in central or eastern European trade. ${ }^{112}$ Sephardic Jews likewise clustered in the commercial sector, with many emerging as international merchants and brokers, while the skilled portion of the Irish influx tended to be dominated by artists and writerswho were joined by a small but influential circle of elite and aristocratic Irish Protestants. ${ }^{113}$ The most studied group of skilled immigrants are the French Huguenots, especially the second wave that arrived in England from the late seventeenth

\footnotetext{
${ }^{106} \mathrm{CC} 8 / 8 / 92 / 353$, NRS.

107 CCB8/8/112/1157, NRS.

${ }^{108} \mathrm{CC} 8 / 8 / 118 / 316, \mathrm{NRS}$.

109 TNA, Consistory Court Depositions, 1720, DL/C/259, fol. 182r.

${ }_{110}$ Debtors' Papers, Case 15c/1/114, Norfolk Record Office.

${ }^{111}$ Westmorland Quarter Session Rolls, WQ/SR/275/12, Kendal Archive Centre.

112 Panikos Panayi, "Germans in Eighteenth Century Britain," in Germans in Britain since 1500, ed. Panayi (London, 1996), 73-94.

${ }^{113}$ Edgar Samuel, “London's Portuguese Jewish Community, 1540-1753,” in Vigne and Littleton, From Strangers to Citizens, 239-46; White, London in the Eighteenth Century, 153-54; Toby Bernard, "The Irish in London and the 'London Irish,' ca.1660-1780," Eighteenth-Century Life 39, no. I (January 2015): 14-40.
} 
century. The cultural and intellectual contribution of individuals within this group was profound, not least in terms of integrating continental thinking into the eighteenth-century Enlightenment. Overall, though, Huguenots specialized in artisanal trades, and especially in the textile industry, a sector that employed over half of English Huguenots in the late seventeenth and eighteenth centuries. ${ }^{114}$ The striking variety of the Scottish contribution in England, the Scots' geographically broad pattern of settlement (albeit favoring London), and their ability to attain ostentatious eminence in a range of fields were not matched by other migrant groups, with the possible exception of the Welsh, whose experiences, at least in London, paralleled the Scots' in terms of their ability to fulfil a wide range of economic functions. ${ }^{115}$

Yet assimilation theory tends to require more than functional success, suggesting that migrants can only be regarded as having assimilated fully when, firstly, the host society stops linking them to a hostile or "othering" discourse, and, secondly, migrants themselves modify their identities to give primacy to their adoptive rather than ancestral homes. ${ }^{116}$ This latter point is problematic for early modern historians, largely because the available sources tend not to offer sufficient insights into individual migrants' self-definition; we cannot, in general, peer into Scots' minds to pinpoint the moment when England rather than Scotland became the primary locus of their identity. The best we can do is to draw inferences from recorded behavior, and in that sense there are indications of the more advanced markers of assimilation being reached. Daniel Defoe's satirical poem The True-Born Englishman (1701) stressed the fluidity of English identity, perceiving it as a sponge that absorbed foreign or invading peoples so that "An Englishman's the common Name of all."117 Defoe's vision of a mongrel Englishness may not have convinced everyone, though it resonates with an understanding of local English communities as shifting entities of people engaged in decisions and actions that would permit productive newcomers to find opportunities for participation and absorption. ${ }^{118}$ Scots were especially capable of taking advantage of the malleability of English identity to become English. The decision of Isobel Macfarlane, after marrying the English preacher Benjamin Burns, to sell her stake in the family lands of Ballancleroch in Stirlingshire to her brother James in 1661 suggests a conscious decision to cut her ties with home in favor of a new English identity. ${ }^{119}$ The poet David Mallet, regarded as among the most Anglicized Scots in eighteenth-century London, signaled his

\footnotetext{
114 Robin D. Gwynn, Huguenot Heritage: The History and Contribution of the Huguenot in Britain (Brighton, 2001), 74-117.

${ }^{115}$ Emrys Jones, "The Welsh in London in the Seventeenth and Eighteenth Centuries," Welsh History Review 10 (January 1980): 61-79.

116 Milton M. Gordon, Assimilation in American Life: The Role of Race, Religion, and National Origins (Oxford, 1964), 70-1. For a recent discussion of assimilation theory as it applies to Scottish migrants, albeit focused on a later period, see Bueltmann, Hinson, and Morton, Scottish Diaspora, 26-31.

117 Daniel Defoe, The True-Born Englishman (London, 1701), 21.

118 Alexandra Shepard and Phil Withington, "Introduction: Communities in Early Modern England," in Communities in Early Modern England: Networks, Place, Rhetoric, ed. Alexandra Shepard and Phil Withington (Manchester, 2000), 1-17.

119 Macfarlane of Ballancleroch Papers, GD61/36, NRS.
} 
determination to integrate by changing his surname from the altogether too Scottishsounding "Malloch."120

For individuals and families achieving such assimilation, penetration of respectable English society could be total. Alexander Monro, the Episcopalian minister and Jacobite-sympathizing principal of Edinburgh University, fled to London in 1691 to escape persecution at home. His son James was only a child at the time of this migration, and his young age allowed him to assimilate well, attending Oxford and becoming the long-serving physician to Bethlam hospital. James Munro's children all carved out respectable lives in England, and indeed three further generations were among his successors at Bethlam. ${ }^{121}$ Here was a family that achieved seamless assimilation, an experience the like of which underpinned the lament in 1739 of Simon Fraser, Lord Lovat, that "when a Scotsman becomes an English man he forgets both his countrey and his best friends." 122 Lovat's informed observation is instructive in recognizing that for some Scots their native identity was less important than fitting in to their new English homes.

Scots found this route of assimilation more open to them than did many other migrant groups. The relatively small Dutch community in England was handicapped by native hostility, particularly during the seventeenth century, when heightened tensions accompanied economic hardship in the 1610s and 1620s, the Anglo-Dutch Wars of the 1650s-70s, and the Glorious Revolution. ${ }^{123}$ German immigrants, whose numbers became significant in the eighteenth century, likewise faced potentially assimilation-blocking hostility, much of it rooted in resentment of the Hanoverian succession (1714) but also drawing on anxiety about the influx of refugees after 1709 known as the "Palatine migration."124 Irish migrants confronted more consistent structural barriers, not least religious, and the disproportionate presence of the poor among the Irish community, especially in London, helped create a derogatory stereotype that provoked sustained hostility and forced many Irish into lives of grinding marginality. ${ }^{125}$ Another group facing strong hostility was the Jews; ingrained anti-Semitism, when combined with a strong sense of ethnic cohesion and cooperation, tended to maintain the community's distinctiveness and separateness. ${ }^{126}$ Even the relative economic success of the Huguenot did not stop them experiencing a sluggish process of assimilation due to a highly developed sense of community and vocal

\footnotetext{
${ }^{120}$ Mary Anne Everett Green et al., eds., Calendar of State Papers, Domestic Series, of the Reign of Charles II, 1660-1685, 28 vols. (London, 1860-1947), 2:214; Jung, David Mallet.

${ }^{121}$ Keith M. Brown and Allan Kennedy, "Becoming English: The Monro Family and Scottish Assimilation in Early Modern England,” working paper.

${ }^{122}$ Papers of Robert Fraser, Advocate, and William Fraser, W. S., RH15/13/52, NRS.

${ }^{123}$ Matthew Lockwood, "Love Ye Therefore the Strangers': Immigration and the Criminal Law in Early Modern England," Continuity and Change 29, no. 3 (December 2014): 349-71, at 361-2; Liên Bich Luu, "Alien Communities in Transition, 1570-1640," in Goose and Luu, Immigrants in Tudor and Early Stuart England, 192-210.

${ }^{124}$ Panayi, "Germans in Eighteenth Century Britain.” As a caveat, wealthier German merchants, many of whom actively sought naturalization as a route to commercial success, may have been able to integrate more fully. Margrit S. Beerbühl, "Naturalization and Economic Integration: The German Merchant Community in 18th-Century London," in Vigne and Littleton, From Strangers to Citizens, 511-18.

125 White, London in the Eighteenth Century, 162.

${ }^{126}$ Ibid., 145-52; Peter Clark, "Migrants in the City: The Process of Social Adaptation in English Towns, 1500-1800," in Migration and Society in Early Modern England, ed. Peter Clark and David Souden (London, 1987), 213-52, 275.
} 
pride in their French culture. ${ }^{127}$ The Scots, aided by overlapping political institutions, a shared if fractious Protestantism, and (outside the Highlands) broadly similar languages, had a head start over these other, more obviously different immigrant groups in terms of assimilating into English society. ${ }^{128}$

Nevertheless, outright rejection of Scottish identity by first-generation migrants appears to have been unusual. Some made visits home to Scotland, other returned there permanently, and most Scots retained some sense of nationality. This makes sense; the theory of "selective acculturation" suggests that immigrant assimilation is likeliest to be successful when first- or second-generation migrants marry the processes of integration with an ongoing anchor in their ancestral culture. Such an anchor is most often provided by robust family or ethnic networks, provided these associations are not so intense as to amount to segregation. ${ }^{129}$ Teasing this theoretical position out of early modern sources is necessarily difficult and somewhat tentative, yet the evidence supports it. For Scots, Protestant churches offered one space within which that identity might be preserved without antagonizing the host community, as would have been the case with Roman Catholic places of worship. Scots congregations have already been cited at Berwick and London, with others existing at Newcastle Silver Street and Kendal in the 1720s and Workington in the 1740s. ${ }^{130}$ While providing fora for Church of Scotland-style worship, these congregations helped sustain an ongoing Scottish identity and maintained ties with the homeland. At London's Swallow Street, for example, the inauguration of William Crookshanks as minister in 1735 was accompanied by a sermon delivered by James Gordon, moderator of the General Assembly. ${ }^{131}$ The Lothbury congregation, meanwhile, began in 1717 to reinforce its sense of community by holding annual dinners, entertaining at the second one the principal of Aberdeen College. To further underline the link with Scotland, the kirk began using sacramental tokens stamped on one side with a thistle. ${ }^{132}$ These congregations offered incoming Scots a ready-made community with which to identify. James Davidson, previously living at St. Andrews, was received into the Swallow Street congregation in 1735 thanks to a certificate provided by his former ministers in Fife. ${ }^{133}$ Further north, at least sixty-five Scots, mostly from the border counties, received similar testimonials in the 1740s and 1750s, allowing them to join an increasing Scottish Presbyterian grouping at Harbottle in Northumberland. ${ }^{134}$ These dynamics can be seen in microcosm among

\footnotetext{
${ }^{127}$ Gwynn, Huguenot Heritage, 202-19; Eileen Barrett, "Huguenot Integration in Late 17th and 18th Century London: Insights from Records of the French Church and Some Relief Agencies," in Vigne and Littleton, From Strangers to Citizens, 375-82.

${ }^{128}$ Linda Colley, Britons: Forging the Nation (New Haven, 2005); Nenadic, introduction to Scots in London, 13-45, at 15. The Scots' experience was probably closer to that of the Welsh, another group whose relative similarity to the English may have presented significant opportunities for assimilation. Jones, "Welsh in London."

129 Alejandro Portes and Rubén G. Rumbaut, Immigrant America: A Portrait (Oakland, 2014), 282-86.

${ }^{130}$ Jonathan Howard Westaway, "Scottish Influences upon the Reformed Churches in North-West England, c. 1689-1829: A Study of the Ministry within the Congregational and Presbyterian Churches in Lancashire, Cumberland and Westmorland" (PhD diss., University of Lancaster, 1996), 187-89.

${ }^{131}$ Minutes of Swallow Street Scotch Kirk, 1734-1770, LMA/4365/A/001, p. 3, LMA.

${ }^{132}$ CLC/182/04962, 235-37, 242-43, LMA.

133 LMA/4365/A/001, p. 4, LMA.

${ }_{134}$ Testimonials received by Harbottle Presbyterian Church, PT33/4, Northumberland Record Office.
} 
the Quakers, whose religious links made it easier to sustain cross-border relations. By the 1680s, Aberdeen Quakers such as Gilbert Molleson, admitted as a freeman draper in 1659, exploited links with their co-religionists in London to procure entry into lucrative London guilds. Others followed, including Patrick Livingstone, a Quaker from Montrose, who turned up in various locales in England between 1659 and 1684. In time, bequests from London-based Friends, such as Elizabeth Dickson's, built meeting houses in Scotland, financed Scottish Quaker missionary endeavors, and provided apprenticeships in Scotland. ${ }^{135}$

Among the global Scottish diaspora, various Scottish societies were formed, such as the Charitable Society of Boston (1657). ${ }^{136}$ In England, the only similar body was the Royal Scottish Corporation, founded by royal charter in 1665 but operating in practice since the start of the century. This charity brought together London Scots with the means to help their fellow countrymen and countrywomen facing hard times, principally through pensions, but it also built a conventional residential poor-relief facility at Blackfriars, where it was based from the 1670s. Although formally a charitable rather than associational body, the corporation displayed some dynamics typical of ethnic clubs. Its charitable relief was restricted to registered members-numbering around three hundred by the 1690s-all of whom had to be Scottish or of Scottish extraction. Office holders were required to have Scottish blood, while its masters had to be Scots-born. The corporation developed a tradition of hosting annual dinners for the benefactors on St. Andrews Day, building a social aspect resembling a London-Scot drinking club that mandated fines for unseemly alcohol-fueled behavior on the part of its office holders. ${ }^{137}$

More usually, the fabled cliquishness of Scottish migrants was informal and fluid, achieved through patronage and socializing rather than institutional linkages. This kind of social networking has long been recognized by historians of migration as helping immigrants improve their material circumstances and shaping the development of the network, while being influenced by its dynamics. ${ }^{138}$ Since familial and ethnic ties often form the basis of many migrants' most important relationships, tracing networks throughout early modern Europe has proved a fruitful way of improving our understanding of Scottish activities overseas, even if there sometimes remain problems in attaching meaning to these networks to move beyond a mere

135 The History of the Worshipful Company of the Drapers of London, 4 vols. (Oxford, 1922), 4:363; Selections from the Writings of Patrick Livingstone: A Faithful Minister of the Gospel in the Society of Friends, and a Patient Sufferer of the Same (London, 1847); Richard H. Field, "Glimpses of Early Friends in Scotland," acc. 2361, p. 48, Friends House London.

${ }^{136}$ Marjory Harper, Adventurers and Exiles: The Great Scottish Exodus (London, 2003), 356-59. The best analysis of Scottish networking, albeit focused on a later period, is Tanja Bueltmann, Clubbing Together: Ethnicity, Civility and Formal Sociability in the Scottish Diaspora to 1930 (Liverpool, 2015).

${ }^{137}$ Justine Taylor, A Cup of Kindness: The History of the Royal Scottish Corporation, a London Charity, 1603-2003 (East Linton, 2003); Original Design, Progress, and Present State of the Scots Corporation at London (London, 1714); A Summary View of the Rise, Constitution, and Present State of the Charitable Foundation of King Charles the Second, Commonly called The Scots Corporation in London (London, 1761), which contains the list of benefactors. See Bueltmann, Clubbing Together, 27-59 for the fullest discussion of Scottish associationalism in England during the nineteenth and early twentieth centuries

${ }^{138}$ Bernice A. Pescosolido, "The Sociology of Social Networks," in 21st Century Sociology: A Reference Handbook, ed. Clifton D. Bryant and Dennis L. Peck (London, 2007), 208-17; John Scott, What Is Social Network Analysis? (London, 2012). 
counting exercise. ${ }^{139}$ Little work has been done on Scottish social networking in England, although two recent micro-studies with eighteenth-century foci offer useful insights into what might be achieved. One of these examples concerns four overlapping commercial networks in London, two of them focused on Scots (Richard Oswald of Caithness and Alexander Grant from Inverness-shire); the second example is the Johnstones of Westerkirk, whose network was imperial in dimension. ${ }^{140}$

Networking allowed Scots to move in and out of their Scottish identity, offering a mutually supportive space while they worked out new relationships, engaged in new experiences, and experimented with the kind of identity shift that might lead to assimilation. Throughout his first stay in London in 1762-63, the key social circle of Edinburgh-born James Boswell was composed almost entirely of Scots, including the lawyer Sir David Dalrymple, the MPs George Dempster and John Mackye, the soldier Andrew Erskine, Ossian "translator" James Macpherson, and the courtier Alexander Montgomerie, tenth earl of Eglinton. ${ }^{141}$ Such social groupings often gravitated toward favored haunts, something noted by Defoe when he wrote in 1720 that "the Scots go generally to the British," a reference to the British Coffee House on London's Cockspur Street near Charing Cross, notorious for its strongly Scottish clientele. ${ }^{142}$ Informal dining groups offered a loose forum for Scots to mix. The activities of one of these has been reconstructed for the period 1710-12, when a core group of seven London Scots, occasionally joined by others, held more than one hundred dinners at numerous taverns and coffee houses throughout the capital. These meetings were social occasions but were also arenas for discussing politics and, since most members were peers or MPs, developing parliamentary strategies. ${ }^{143}$

Nor was an overt preference for Scottish fellowship restricted to the well-to-do residents of London. Michael Anderson, who claimed to be a Chelsea pensioner, was traveling through North Yorkshire in 1719, when he met a group of two men and one woman, with whom he readily agreed to stop at a local alehouse after discovering that one of the group was a fellow Scotsman. ${ }^{144}$ The maintenance of Scottish contacts could be facilitated by the practice among some lodging-house owners of specializing in the migrant market. James Mcmock maintained an establishment in St. Dunstan's Parish in east London that he admitted in 1639 had catered almost exclusively to a Scottish clientele for almost thirty years, while a Shrewsbury tailor named Willcox was reported in 1683 to have "very long entertained Scotchmen," usually traveling hawkers in need of temporary lodgings. ${ }^{145}$ What is harder to determine is if and when these Scottish connections ceased to matter and whether any general observations might be made about life cycle or duration in England that

\footnotetext{
${ }^{139}$ Murdoch, Network North, 3.

${ }^{140}$ Hancock, Citizens of the World; Rothschild, Inner Life of Empires.

${ }^{141}$ Boswell, London Journal.

${ }^{142}$ Barry Lillywhite, London Coffee Houses: A Reference Book of Coffee Houses of the Seventeenth, Eighteenth, and Nineteenth Centuries (London, 1963), 132-35.

${ }^{143}$ Clyve Jones, "A Westminster Anglo-Scottish Dining Group, 1710-12: The Evidence of Lord Ossulton's Diary," Scottish Historical Review 71, nos. 191/192 (April-October 1992): 110-28.

${ }^{144}$ Quarter Session Bundles, QSB/1719, North Yorkshire County Record Office.

145 TNA, SP16/418, fol. 104, item 42; TNA, State Papers Domestic, Charles II, SP29/434.
} 
affected the desire to identify with other Scots rather than English neighbors and friends.

A William Jamiesson observed in 1680 that while there were enough Scots in London to support him, there were not enough of them to find him employment in the city, suggesting that the patronage of a fellow countryman was crucial in finding work. ${ }^{146}$ There are indications that Scots even in the lower occupational groupings developed crucial networking strategies. Gilbert Falconer traveled from Aberdeenshire in 1702 to become an apprentice draper to Gilbert Molleson, a Scot with whom there was likely a family connection. A year later, Falconer's sister, Jane, joined him as an apprentice draper to Molleson. ${ }^{147}$ There were several instances in London of apprentices being bound to men sharing their surname, probably indicating a family connection. Thomas Pierson from Arbroath was apprenticed as a glover to David Pierson in 1678; John Ferguson, a native of Edinburgh, bound himself to a glass seller also called John Ferguson in 1709; and John Bassington, cloth worker of Hoxton, took his namesake from East Lothian as apprentice in 1754. ${ }^{148}$ In Newcastle, William Currey was apprenticed as a smith in 1716, and after being admitted at the end of his apprenticeship, he proceeded to take two apprentices from Roxburghshire, brothers John and Adam Elliott, in 1729 and 1730 respectively. ${ }^{149}$ At Berwick, networking was sometimes demonstrably overlain by ties of kinship; thus, Robert Fleming of Foulden was bound as an apprentice tailor to his brother John in 1727, and George Douglas from Ethrington Mill in Berwickshire was apprenticed in 1755 to his uncle and namesake, a glazier. ${ }^{150}$

If Scots were open to the identity shift required for complete assimilation, the attainability of this goal was enhanced by the relative absence of significant and sustained English prejudice. That does not mean that hostility was wholly absent. Indeed, England developed a clear Scotophobic discourse, rooted, above all, in accusations of poverty. ${ }^{151}$ Some Scots migrants were unfortunate enough to be arrested as vagrants either because they were poor and had moved to England in search of work, or their circumstances had changed while in England, driving them down into poverty. These were a minority of the identifiable Scottish migrants in England, but they had a disproportionate effect on the popular imagination. ${ }^{152}$ Thus a report from 1637 states the "majority" of the eighteen hundred keelmen, watermen, and general laborers in Newcastle out of work due to inclement weather were Scots or Borderers who, along with their wives and children, created a potential problem for local magistrates. ${ }^{153}$ English mockery of Scots surfaced in literary stereotyping that picked up on that combination of poverty and otherness. One particularly

\footnotetext{
146 Russell Papers, RH15/106/305/11, NRS.

${ }^{147}$ Records of London's Livery Companies, accessed 13 August 2015, www.londonroll.org/event/?company =drp\&event_id=DREW2277, www.londonroll.org/event/?company=drp\&event_id= DREW2278.

${ }_{148}$ Webb, Apprenticeship Registers, 4:16, 5:10; Records of London's Livery Companies, accessed 13 August 2015, www.londonroll.org/event/?company=clw\&event_id=CLEB17043.

${ }^{149}$ GU.SM/36/1, TWA.

${ }^{150}$ Berwick Enrolments, BBA/B6/3-4, BRO.

${ }^{151}$ Bruce R. Galloway and Brian P. Levack, eds., The Jacobean Union: Six Tracts of 1604 (Edinburgh, 1985), 178; Anthony Weldon, The Court and Character of King James (London, 1817), 18.

152 Brown et al., "Scots and Scabs."

${ }^{153}$ Extracts from the Records of the Company of Hostmen or Newcastle upon Tyne (1901), 78n.
} 
caustic contribution, dating from 1705, asserted that the Scots' native accomplishments were limited to "Pedantry, Poverty, Brutality, and Hypocrisie." 154 Scots were often compared to pests or disease, a characterization that served to emphasize their perceived inferiority while tapping into ingrained fears about poor Scottish migrants overrunning and corrupting England. An anonymous poem, probably written in the mid-seventeenth century, lamented that "like Jews [the Scots] spread, and as Infection fly," and concluded that Scotland was "a Nation Epidemical." 155 Such stereotyping found its way into popular culture, most notably in the emergence of the "Scotch ballad" genre, which played upon preconceived ideas by presenting Scottish characters as marked by faithless licentiousness. ${ }^{156}$ All of this was complemented, especially after the advent of Jacobitism, by powerful Scotophobic iconography, principally deployed in political prints that drew upon common motifs - alien clothing, the thistle, poverty, uncleanliness, and rampant sexualityto construct a recognizable image of the Scottish "other."157

The impact of this Scotophobic discourse on the lives of migrants is unclear. Scattered examples of anti-Scottish activity can be found; for example, in 1725 the schoolmaster of Longhaughton, John Shearer, complained to the justices of the peace for Northumberland that a charge of "Lewd Life" recently levied against him by a local farmer was actually informed by the fact that "I am a Scottsman." Outright hostility to Scots was most common in London when political tensions were acute. ${ }^{159}$ Some of the most infamous episodes, taking place during the widely unpopular ministry of the Scottish prime minister, the earl of Bute, occurred in December 1762 when a theatre audience, catching sight of Highland officers, chanted, "No Scots! No Scots! Out with them!" However, that particular outbreak of anti-Scottish behavior was whipped up in satirical prose and scathing cartoons by John Wilkes through his North Briton newspaper in opposition to its pro-government rival, The Briton, the vehicle for Tobias Smollett. ${ }^{160}$ Beyond high politics, tensions were more likely to arise when English communities felt that their financial or professional interests were put at risk by Scottish competition. For example, in 1667 Scottish cattle imports stimulated concern in Cumberland, where they were perceived to threaten local suppliers. ${ }^{161}$ Reports of Scotophobic unrest in Newcastle during May 1672 were occasioned by an unusual and temporary influx of several hundred rowdy Scottish soldiers en route to service in the Third Anglo-Dutch

\footnotetext{
154 "E. B.," A Description of Scotland and its Inhabitants (London, 1705), 2-3.

155 "A Satyre on the Scots," in Poems on Affairs of State from 1640 to this Present Year 1704, 3 vols. (London, 1704), 3:32-35.

156 Thomas Farmer, The Scotch Lass Deceiv'd by her Bonny Lad Jockey (London, c. 1688)

${ }^{157}$ Gordon Pentland, "We Speak for the Ready': Images of Scots in Political Prints, 1701-1832," Scottish Historical Review 90, no. 229 (April 2011): 64-95.

${ }^{158}$ QSB/65, Northumberland Record Office.

159 Galloway, Union of England and Scotland, 170-1; Christopher A. Whatley and Derek Patrick, The Scots and the Union (Edinburgh, 2007), 212-14; Allan I. Macinnes, Clanship, Commerce and the House of Stuart, 1603-1788 (East Linton, 1996), 211; K. W. Schweizer, "English Xenophobia in the 18th Century: The Case of Lord Bute," Scottish Tradition, 22 (1997): 6-26; Nenadic, introduction to Scots in London, 13.

${ }^{160}$ Boswell, London Journal, 71-72; Adam Rounce, "“Stuarts without End': Wilkes, Churchill and AntiScottishness," Eighteenth-Century Life 29, no. 3 (Fall 2005): 20-43.

${ }^{161}$ DLONS/L/13/1/15, Cumbria Archive Services.
} 
War. Newcastle operated local discriminatory processes before 1707 in formally excluding Scots from guilds such as the smiths or the masons. ${ }^{162}$ Professional jealousy appeared to be the issue in 1747 when a petition was presented to the Royal College of Physicians bemoaning the number of allegedly ill-educated Scottish (and Dutch) doctors active in England who were bringing the profession into ill repute; it requested stern measures to crack down on these interlopers. ${ }^{163}$

There is evidence to suggest that over the course of the early modern period, England became more xenophobic and intolerant of foreigners, but Scots faced relatively low levels of prejudice, and the more colorful examples of Scotophobia were targeted, localized, and temporary. ${ }^{164}$ Nothing suggests that the undoubted existence of anti-Scottish stereotypes resulted in broader structural barriers to assimilation. Indeed, the growing prominence, particularly in the eighteenth century, of complaints about Scottish success (such the assertion of Charles Mordaunt, third earl of Peterborough, in Queen Anne's third British Parliament that some Scots made more money in England than they derived from vast landed estates in Scotland), while at one level a familiar reaction against unwelcome competition, tacitly reflected the limited impact of anti-Scottishness on the real-world prospects of Scots migrants. ${ }^{165}$

\section{CONCLUSION}

Responding in 1703 to criticism of Scotland in the context of the debate over AngloScottish relations, the London-based pamphleteer George Ridpath protested the "many Thousands of Scots-Men in England" while noting that "England reaps the Benefit of their Labour and Industry." 166 Here is an early modern version of the current argument that skilled migrants are a valuable asset, economically and culturally. Just how many thousands of Scots were in England at various points in time between the arrival of a Scottish king in 1603 and the appointment of a Scottish prime minister in $\mathbf{1 7 6 2}$ is impossible to say, but it was not large enough to arouse widespread comment. ${ }^{167}$ Some of these individuals' lives are documented, but many thousands more have left little or no record of their existence-especially the large numbers of Scots and their families working on the Newcastle docks, the soldiers and sailors discharged at English ports, and the multitude of people who

\footnotetext{
${ }^{162}$ Masons' Ordinances, GU.MS/1/1, 1 September 1581, TWA; GU.SM/36/1, TWA; Green et al., Calendar of State Papers, Domestic Series, 12:399, 439, 452, 457, 598, 13:2-3, 53, 82-83, 261.

163 "A. Z." An Address to the College of Physicians and to the Universities of Oxford and Cambridge; Occasion'd by the Late Swarms of Scotch and Leyden Physicians (London, 1747).

${ }^{164}$ Ned Landsman, "Pluralism, Protestantism, and Prosperity," in Beyond Pluralism: The Conception of Groups and Group Identities in America, ed. Wendy F. Katkin, Ned Landsman, and Andrea Tyree (Chicago, 1998), 105-24.

165 William Pittis, The History of the Third Session of the Last Parliament (London, 1713), 116-17.

166 [George Ridpath], Case of Scots-men Residing in England and in the English Plantations (Edinburgh, 1703), 10.

167 The London-based calculations mentioned in the text above between notes 14 and 15 above imply that the 3,000-strong dataset under discussion in this article may have captured somewhere around $0.75-1$ percent of Scottish migrants in England between 1603 and ca. 1760, which would in turn suggest a migrant population of 300,000 to 400,000 Scots, but these figures, perhaps suspiciously large, are really little more than guesswork.
} 
disappeared into the melting pot of London. Quite what their collective contribution was to England, and to the making of Britain, is difficult to quantify, but it was more tangible than simply contributing to some imagined British identity shaped by commerce, Protestantism, and opposition to an "other."168 As Ridpath rightly argued, these were real people doing real jobs to England's benefit. What the above evidence indicates is that, for all the negative bluster about the Scots that emerged episodically, and in spite of the populist caricatures embedded in English society, in practice most Scots appear to have been tolerated or even welcomed in England precisely because of the contribution they were seen to be making. Whether their roles were in high office or within aristocratic circles, as clergymen or doctors, soldiers or sailors, apprentices or keelmen, Scots migrants faced comparatively few obstacles from their English neighbors, or from local magistrates, who valued their skills or labor above any latent prejudices within the host community. Those Scottish migrants who were subjected to harsh treatment were singled out, largely on legal grounds, precisely because they were vagrants or criminals. Here is evidence of segmented assimilation at work, because the host community was sufficiently discerning to differentiate between those migrants perceived to be of value and those seen to be undesirable.

Scots migrants, too, differentiated themselves by their behaviors. England was a land of opportunity, one of a number of options available to people with the desire, or the need, to leave Scotland. But while for a minority of individuals it was only a place to live and work for a period while retaining strong links with a homeland, for many others England became home. For this latter group, it was relatively easy to assume a new identity from the variety on offer: Anglo-Scottish, North British, British, and even English. Indeed, it seems likely that for the overwhelming majority of Scots who migrated to England, becoming British, or English, was the most common outcome, if not for themselves, then certainly for their descendants. Given that for centuries Scots had migrated and morphed into being French, Dutch, or Swedish and could now become colonial Americans, this is unsurprising, but on this scale it was new, and it was different from the experience in Ireland, where the Ulster Scots emerged as an ethnic group distinct from the native Irish. That large numbers of Scots disappeared into England with such ease suggests not only a relatively open host community but an adaptive immigrant population who found it relatively easy to make that transition in spite of their reputation for having their own strong national identity. The reality was that their Scottish identity was tradable.

What did this mean for Scotland beyond the usual narrative of the loss of population and talent that has always been a feature of Scotland's history? It is clear that Scotland lacked the means to support its growing population and that it had an oversupply of skilled and aspirational individuals who had to fulfill their ambitions elsewhere. That large numbers of them headed south to England and remained there meant that Scots were not only scattered throughout an expanding imperial system but had a powerful network across England with a strong concentration in London. One of the reasons for the success of the Union was that Scots could easily be at home in England, allowing other Scots ready access to the networks

${ }^{168}$ Colley, Britons. 
they created. With its own powerful institutions and relatively little appetite in England for interference north of the border, or desire of English people to migrate there, Scotland had the dual benefits of a homeland free from any threat of colonialism and open access to every level of English society. It was an opportunity the Scots seized and exploited.

Can any general observations be drawn from this case study of successful migration? The political and legal context was important; the growth in migration southward followed the formation of a single executive arm of government in 1603 and the judgment on naturalization that followed a few years later, accelerating after the creation in 1707 of a unified legislature and a free market. Secondly, most Scots who made their way to England were sufficiently wealthy, skilled, or responsive to shortages in local labor markets to be viewed positively by their English hosts. In certain circumstances, political loyalty and economic competitiveness placed strains on relationships that unscrupulous politicians sought to exploit, but this was not a common experience. Thirdly, in an age when a man from Northumberland and a woman from Cornwall were considered different from one another and from Londoners, (Lowland) Scots were just another variation in the patchwork of British regional identities. They were not so different from the English in their speech, customs, appearance, or religion as to be perceived as alien, and for those who chose it, assimilation was relatively easy. Finally, Scottish immigration, though ultimately substantial, was measured, only building up pace in the course of the eighteenth century and never growing faster than the needs of the English economy to absorb it. The Scottish experience suggests that migrations are likeliest to succeed when the political, economic, and attitudinal conditions of the host society are amenable, and when migration is gradual and responsive to the needs and capacity of the native community. 